\title{
Isolation, Identification and Antimicrobial Susceptibility Tests of E. Coli and Salmonella from Diarrheic Calves in and Around Sebeta Town
}

Olana Merera ( $\nabla$ olanamerea@gmail.com )

Samara University https://orcid.org/0000-0001-5513-0193

Atnafu Regassa

Samara University

Fikru Gizaw

Arsi University

Biyansa Adugna

Samara University

Shubisa Abera

NAHDIC

Research article

Keywords: Calves, Diarrhea, E. coli, Ethiopia, Sebeta, Salmonella

Posted Date: June 19th, 2020

DOl: https://doi.org/10.21203/rs.3.rs-32263/v1

License: (c) (i) This work is licensed under a Creative Commons Attribution 4.0 International License.

Read Full License 


\section{Abstract \\ Background}

Calves are important assets for replacement of cows for the future dairy and beef herd sustainability. However, calf hood diseases have a significant financial impact on dairies resulting from treatment costs, genetic loss, and impaired future performance.

\section{Objective}

The purpose of the present research is for isolation and identification of Salmonella and E. coli infection in diarrheic calves, assessing risk factors for occurrence of calf diarrhea and examining antimicrobial susceptibility of isolated bacteria's.

\section{Methodology:}

A cross- sectional study on the isolation, identification and antimicrobial susceptibility of $E$. coli and Salmonella was carried out on calves up to two months of age from November, 2018 to March, 2019 in and around Sebeta town, Ethiopia. The detection of E. coli and Salmonella was done by conventional bacteriological method and biolog (semiautomatic machine). The data was analyzed by Stata 12 .

\section{Results}

It was found that the detection rate of E. coli and Salmonella from 129 sampled diarrheic calves were 65 $(50.3 \%)$ and $8(6.2 \%)$ respectively. Age $(E$. coli, X2 = 9.429, P = 0.024; Salmonella, X2 = 8.161, P = 0.043), sex ( $E$. coli, $\mathrm{X} 2=11.225, \mathrm{P}=0.001$, though not significant for Salmonella) and feeding time of colostrum $(X 2=7.510, P=0.023$; Salmonella, $X 2=6.678, P=0.036)$ were risk factors associated with the incidence of $E$. coli and Salmonella. The antimicrobial study revealed that most of the $E$. coli was highly susceptible to sulphamethoxazole冈trimethoprim, chloramphenicol, gentamicin and ampicillin and highly resistant to tetracycline (29.23\%) and followed by polymixin B (6.1\%), and from isolates of Salmonella all showed $100 \%$ susceptibility for sulphamethoxazole冈trimethoprim and polymixin B, $87 \%$ to Ampicillin, chloramphenicol and tetracycline while $75 \%$ to gentamicin.

\section{Conclusion}

Based on those findings, it can be concluded that calf diarrhea was found to be high and could affect dairy production in the study area. The triggering ecological, social and bacterial genetic factors for the widespread distribution of multidrug resistant Salmonella and E.coli are not known, thus requires 


\section{Introduction}

Livestock is an integral part of the agricultural production system in some countries and plays an important role in national economy as well as in socio-economic development of millions of rural household. Ethiopia basically constitutes an agrarian society; the socio-economic activities of about $85 \%$ of the population are based on farming and animal husbandry. Livestock plays a critical role for the majority of the Ethiopian population. Domestic animals are mainly used as drought animals, source of milk, meat, hide and skin and as pack animals. Apart from this they also serve as a means of risk diversion and accumulation of wealth among the rural community [1].

Dairy production is a critical issue in Ethiopian livestock -based society where livestock and its products are important sources of food and income. The substantial demand-supply variance in milk and milk products for the major urban centers in Ethiopia is a great opportunity for the development and flourishing of peri-urban dairy farms. Peri-urban and urban dairies are intensive production systems, which keep high-grade cows and have improved management practices. This is usually associated with increased susceptibility to disease, poor survival rate and poor reproductive. The country has large potential for dairy development mainly due to large livestock population, the favorable climate for improved high yield breed, and relatively diseases-free environment [2]

Newly born calves are important source of animal production for either meat or breeding worldwide. Calves are important assets for replacement of cows for the future dairy and beef herd sustainability. It is needed to rear healthy calves. In the calf, losses have been as high as $50 \%$ of calf crop because of poor management and low adaptation of exotic dairy breed to tropical environment [3]. Calf hood diseases have, therefore, a significant financial impact on dairies resulting from treatment costs, genetic loss, and impaired future performance [4]. Diarrhea is a leading cause of economic losses to most countries [5]. Its etiology is complex involving management, environmental, nutritional, physiological variations and variety of pathogens including bacteria, viruses, protozoa and intestinal parasites are described as important agents causing diarrhea (either separately or in combination) in calf [6].

Calf diarrhea caused by bacterial infection has a bad effect on the dairy industry all over the world when calves are reared intensively. It involves significant economic loss for labor and capital, calf mortality, loss in calf value and veterinary costs $[7 ; 8]$. Among these bacteria E.coli and salmonella are believed to be the major microbial causes of calf diarrhea [9;10]. According to Lorenz [11], calf morbidity and mortality by diarrhea have short-term and long-term detrimental effects on performance of a dairy farm. They impair both growth rate and replacement capacity of the herd. The economic losses occur not only from mortality but also from treatment costs and time spent on care as well as subsequent chronic ill, thrift and impaired growth performance [12]. In order to increase the productivity per livestock unit without increasing livestock numbers and to devise preventive measures as well as to reduce losses during the initial months of life it is important to identify the etiological agents involved in calf diarrhea $[13 ; 14]$. 
Current treatment regimens for the treatment of neonatal calf diarrhea center on antimicrobial therapy and fluid therapy. Antimicrobial agents are considered popular to fight diarrhea in calves. Nevertheless, their wide spectrum of activity, the emergence of microbial tolerance of different antimicrobial agents has become a well- known phenomenon, which represents a major concern. Resistance to antimicrobial agents was frequently occurred in Salmonella species and E. coli particularly in pre-weaned dairy calves [16]. Antibiotic resistance to bacteria is a serious and growing phenomenon and has emerged as one of the preeminent public Health concerns of this century. The choice of which antibiotic is likely to be most effective requires knowledge of potential resistance. The practice of under dosing, over dosing as well as indiscriminate usage of drugs are not uncommon in Ethiopia, As a result, bacterial strains are being developed which are multidrug resistant and new types of antibiotics are required for the prevention and control of diseases.

Discontinuation or incomplete course of treatment and continuous indiscriminate uses of antibacterial drugs against diarrheal infection of man and animal creates a potential health risk to animals and humans in terms of drug residues and the development of resistant bacterial strains. Although routine laboratory isolation and drug sensitivity testing are expensive and impractical, the periodical check of the pattern of the drug sensitivity of organisms is more important. It is, therefore, important that sensitivity of different bacteria isolated from diarrheic calves needs to be studied from time to time in order to formulate appropriate therapeutic measures [17]. In order to increase the productivity per livestock unit without increasing livestock numbers, it is important to identify the etiological and predisposing factors involved in calf diarrhea in order to devise preventive measures and reduce losses during the initial months of life [18; 13].

Dairy farming is a growing livestock production system in Ethiopia. It is primary source of income for urban and peri-urban poor communities. Because of better availability of milk market, most of the dairy farms are concentrated in urban and peri-urban areas of the country. They also increase the use of exotic dairy cattle and their crosses in order to enhance milk production. In Ethiopia in general calf morbidity and mortality due to calf diarrhea is a challenging problem for dairy producers. However, there is no coordinated surveillance and assessment for prevalence and risk factors inducing this problem and there is also little information available regarding to this problem. Accordingly, the objectives of this research were to isolate and identify of salmonella and $E$. coli infection in diarrheic calves, to assess risk factors for occurrence of calf diarrhea and to examine antimicrobial susceptibility of isolated bacteria's in and around Sebeta town.

\section{Methodology}

\section{Description of study area}

The study was conducted on diarrheic calves between November 2018 to March 2019 in and around Sebeta town, located at suburb of Addis Ababa in Oromia special zone surrounding Finfinne of Oromia 
meters (7730 feet) above sea level. The average temperature is $17.4^{\circ} \mathrm{C}$ and the town receives annual rainfall of $1650 \mathrm{~mm}$, the monthly precipitation is being $150 \mathrm{~mm}$ are mostly wet and below $30 \mathrm{~mm}$ mostly dry. The farming system of the study area is intensive, semi-intensive and extensive. However this study was conducted on the intensive farming system.

\section{Study population}

Study animals were local and crossbred calves managed under intensive management system in and around Sebeta town. The farms and house hold where were visited during the study period to enable us to observe the health status of the calves. During each visit the calf's management, housing and sanitation situations were also observed. The sick animals were treated after the clinical investigation and after the necessary samples were collected. Age, sex, body condition, manure removal, breed of each animal were recorded during sample collection.

\section{Study design}

A cross sectional study was conducted in dairy farms (small, medium sized and large) in and around Sebeta from November 2018 to march 2019 and a purposive sampling methods used to collect samples from calves that showed major clinical sign of diarrhea (elevated temperature, depression, dehydration, reduced suckling reflex, rough hair coat, loss of weight, weakness and soiling of hind quarter and tail with diarrheic feces [19].

\section{Fecal sample collection, storage and transportation}

From November 2018 to march 2019 a total of 129 diarrheic samples were collected purposively from the rectum of the calves less than two month old with surgical gloves and placed in sterile dry screw-cup universal bottles and transported to the Microbiology Laboratory of NAHDIC in an ice box within 3-4 hrs of collection from farms and small holder which found in and around Sebeta town. The samples were collected from calves showed clinical sign of diarrhea, but had not been treated with antibiotics before. At the time of sampling the name of the farm, date of sampling, consistency of feces, age, breed, body condition, tag number; and feeding management practices as well as past history of diarrhea were recorded for each calf on a recording format. A calf was considered as diarrheic if feces were semi-fluid (loose) to fluid with or without mucus and/or blood. In the laboratory, isolation and identification of Salmonella and E. coli were conducted using conventional methods as described by [40].

\section{Isolation and identification Salmonella}

The fecal samples for isolation of salmonella were done briefly as follows: $1 \mathrm{~g}$ of feces was pre-enriched in $9 \mathrm{ml}$ of buffered peptone water (BPW) and incubated overnight at $37^{\circ} \mathrm{C}$. From the overnight culture $100 \mu \mathrm{l}$ pre-enriched suspension was added into $10 \mathrm{ml}$ of Rappaport-Vassiliadis enrichment Broth (RVS) (Oxoid, USA) and incubated at $42^{\circ} \mathrm{C}$ for $24 \mathrm{hr}$. cultures showing characteristic growth on RVS broth was streaked on to Xylose Lysine deoxychlorate (XLD) (Oxoid, USA) selective media and the plates were incubated at $37^{\circ} \mathrm{C}$ for 24 to $48 \mathrm{~h}$. Then the colonv was examined for the presence of typical salmonella Loading [MathJax]/jax/output/CommonHTML/fonts/TeX/fontdata.js 
colonies. Super imposed on the red colonies is the production of $\mathrm{H} 2 \mathrm{~S}$ so red colonies is with a black center in Xylose lysine deoxychlorate (XLD) medium can likely be salmonella, which was subjected to successive biochemical tests after cultured pure colonies on nutrient agar. After suspected colonies were selected and cultured on nutrient agar media, biochemical tests: TSI test, citrate utilization test, Urease test, Indole test, methyl red test and Vogues Proskauer test were conducted. For confirmation and for sub species identification of isolated bacteria, Biolog (semiautomatic machine) was utilized.

\section{Isolation and identification of E. coli}

To detect E. coli, samples were inoculated on MacConkey's agar and Eosin Methylene Blue (EMB) agar used for the purpose of observing growth of E. coli and incubated at $37^{\circ} \mathrm{C}$ overnight. The presence of growth on MacConkey's agar was used as primary criteria to proceed for isolation and identification of $E$. coli. Furthermore the colony characteristics observed on MacConkey's agar was used to classify suspected bacteria isolated into two groups: lactose fermented and non-lactose fermented. Suspected $E$. coli colonies were presumptively identified their lactose fermenting character (pink colonies), were confirmed as $E$. coli according to [20; 21; 22]. Lactose positive colonies sub cultured on Eosin methyl blue (EMB) agar medium to identify selectively E. coli. Colonies producing metallic sheen or blue-black to brown color on EMB agar were considered as having E. coli. In addition, various biochemical tests were done for the confirmation of E. coli [22]. All isolated colonies were sub-cultured on nutrient agar to obtain pure colony for further biochemical tests:-TSI test, citrate utilization test, Urease test, Indole test, methyl red test and Vogues Proskauer test were conducted. For confirmation, Biolog (semiautomatic machine) 65 confirmed E. coli isolate from each positive sample was stored at Brain heart infusion slant agar until drug susceptibility testing.

\section{Antimicrobial susceptibility test}

The antimicrobial susceptibility test was performed following the standard agar disk diffusion method according to [41] using commercial antimicrobial disks. The selection criteria of the antibiotics depended on the regular use of the antimicrobials in the ruminants, potential public health importance and recommended from the guideline of antimicrobial susceptibility testing. Pure colonies incubated for 6 hours in Tryptone Soya Broth (Oxid, England) will be made to have a turbidity of 0.5 macFarland standards and inoculated on already prepared Muller-Hinton agar (Bacton Dickinson company and Cockeysville USA). Antibiotic discs were then placed and incubated for 24 hours at $370 \mathrm{o}$. The results will be classified as resistance, intermediate and susceptible after the zone of inhibition of bacterial growth is appreciated, hence a standardized table is given by the manufacturer for this classification [41]

The following disks were used: Gentamicin $(10 \mu \mathrm{g})$, Ampicillin $(10 \mu \mathrm{g})$, Chloramphenicol $(30 \mu \mathrm{g})$, sulphamethoxazole邓trimethoprim $(30 \mu \mathrm{g})$, polymixin B and Tetracycline $(30 \mu \mathrm{g})$.

\section{Data management and analysis}

The data generated from the study was arranged, coded and entered to Excel spread sheet (Microsoft ${ }^{\circledR}$ office excels. 2007). Prevalence of Salmonella and E.coli were calculated as a percentage of Salmonella Loading [MathJax]/jax/output/CommonHTML/fonts/TeX/fontdata.js 
and E.coli culture-positive samples among the total number of samples examined. Chi-square test was done by STATA version 12 to study association between Salmonella and E.coli isolates and risk factors. The significance level was set at 0.05 and $95 \%$ confidence level.

\section{Result S And Discussions}

Laboratory examination of $129 \mathrm{fecal}$ samples from diarrheic calves during the study period was done to isolate and identify Salmonella and E. coli associated with calf diarrhea. The overall occurrence of E.coli and Salmonella from isolated samples were $65(50.3 \%)$ samples revealed the presence of E. coli and 8 (6.2\%) of isolates were identified as Salmonella, showed in Table 1.

Table 1

The overall occurrence of E. coli and salmonella isolated from diarrheic calf in and around sebeta town.

\begin{tabular}{|lllll|}
\hline Isolates & $\begin{array}{l}\text { Sample } \\
\text { type }\end{array}$ & $\begin{array}{l}\text { Total } \\
\text { number } \\
\text { examined }\end{array}$ & Number of + ve (Prevalence) & 95\% confidence interval \\
\hline E. coli & Feces & 129 & $65(50.3 \%)$ & $41.6-59.1$ \\
\hline Salmonella & Feces & 129 & $8(6.2 \%)$ & $1.98-10.4$ \\
\hline
\end{tabular}

The culturally and biochemically identified Salmonella isolates were further tested for confirmation and sub species identification by using Biolog (semiautomatic machine). A total of 8 Salmonella isolates, consisting of two different subspecies were identified. Of the sub species identified during study were $S$. enterica subspecies enterica and S. enterica subspecies thyphimurium. S. enteric subspecies enterica constitutes $75 \%$ (6 isolates) and $S$. enterica subspecies thyphimurium constitutes $25 \%$ ( 2 isolates).

The distribution of $E$. coli and salmonella among calves of different age groups, sex, farm size and times of colostrum feeding was determined. In this regard, the isolation rates of $E$. coli decreased with increasing age of calves and when the times of colostrum feeding, the highest being in calves of $<2$ week old and as the time of colostrum feeding exceed 6 hours. There was statistically significant difference between the age groups of $E$. coli and salmonella isolation rate. The difference in isolation rates of $E$. coli in different age groups and times of colostrum feeding were statistically significant $(p<0.05)$ which is showed in the following Tables 2,3 and 4. 
Table 2

Association between supposed risk factors and isolated $E$. coli from diarrheic calves

\begin{tabular}{|c|c|c|c|c|c|}
\hline Risk factors & Category & Total sample & No. of Positive & $x^{2}$ & P-value \\
\hline \multirow[t]{3}{*}{ Sex } & Female & 30 & 48 & \multirow[t]{3}{*}{11.25} & \multirow[t]{3}{*}{0.001} \\
\hline & Male & 35 & 16 & & \\
\hline & Total & 65 & 64 & & \\
\hline \multirow[t]{5}{*}{ Age } & 2 weeks & 28 & 69 & \multirow[t]{5}{*}{9.429} & \multirow[t]{5}{*}{0.024} \\
\hline & 2-4weeks & 26 & 47 & & \\
\hline & $4-6$ & 9 & 11 & & \\
\hline & $6-8$ & 2 & 2 & & \\
\hline & $>8$ & 65 & 129 & & \\
\hline \multirow[t]{4}{*}{ Feeding time of colostrum } & $>24 \mathrm{hrs}$ & 36 & 50 & \multirow[t]{4}{*}{7.51} & \multirow[t]{4}{*}{0.023} \\
\hline & $6-12 \mathrm{hrs}$ & 19 & 9 & & \\
\hline & $<6 \mathrm{hrs}$ & 10 & 5 & & \\
\hline & Total & 65 & 64 & & \\
\hline \multirow[t]{4}{*}{ Farm size } & Small & 9 & 17 & \multirow[t]{4}{*}{2.156} & \multirow[t]{4}{*}{0.34} \\
\hline & Medium & 20 & 33 & & \\
\hline & Large & 36 & 79 & & \\
\hline & Total & 65 & 129 & & \\
\hline
\end{tabular}


Table 3

Association between supposed risk factors and isolated salmonella from diarrheic calves

\begin{tabular}{|c|c|c|c|c|c|}
\hline Risk factors & Category & Total sample & No. of Positive & $x^{2}$ & P-value \\
\hline \multirow[t]{6}{*}{ Age } & $>2$ weeks & 69 & 3 & \multirow[t]{6}{*}{8.16} & \multirow[t]{6}{*}{0.043} \\
\hline & 2-4 weeks & 47 & 4 & & \\
\hline & $4-6$ weeks & 11 & 0 & & \\
\hline & $6-8$ weeks & 2 & 1 & & \\
\hline & \multicolumn{3}{|l|}{$>8$ weeks } & & \\
\hline & Total & 129 & 8 & & \\
\hline \multirow[t]{4}{*}{ Feeding time of colostrums } & $>6 \mathrm{hrs}$ & 86 & 2 & \multirow[t]{4}{*}{7.2} & \multirow[t]{4}{*}{0.05} \\
\hline & 6-12hrs & 28 & 4 & & \\
\hline & $>24 \mathrm{hrs}$ & 15 & 2 & & \\
\hline & Total & 129 & 8 & & \\
\hline
\end{tabular}


Table 4

Association of E. coli with different factors in diarrheic calves

\begin{tabular}{|c|c|c|c|c|c|c|}
\hline Variable & Category & $\begin{array}{l}\text { Number } \\
\text { of + ve }\end{array}$ & $\begin{array}{l}\text { Crude } \\
\text { OR }\end{array}$ & $\begin{array}{l}\text { Adjusted } \\
\text { OR }\end{array}$ & $95 \% \mathrm{Cl}$ & p-value \\
\hline \multirow[t]{4}{*}{ Farm size } & Total & $65 / 129$ & 0.86 & & $0.47-1.56$ & 0.65 \\
\hline & Small & $9 / 17$ & & & & \\
\hline & Medium & $20 / 33$ & & & & \\
\hline & Large & $36 / 79$ & & & & \\
\hline \multirow[t]{3}{*}{ Sex } & Total & $65 / 129$ & 6.89 & & $2.57-18.45$ & 0.000 \\
\hline & Male & $35 / 51$ & & 7.4 & $2.8-19.4$ & 0.00 \\
\hline & Female & $30 / 78$ & & 1 & & \\
\hline \multirow[t]{4}{*}{ Age } & Total & $65 / 129$ & 2.46 & & $1.24-4.82$ & 0.01 \\
\hline & $>2 w k$ & $28 / 69$ & & 1 & & \\
\hline & $2-4 w k$ & $26 / 47$ & & 1.7 & $0.7-4.2$ & 0.22 \\
\hline & $5-8 w k$ & $11 / 13$ & & 15.1 & $2.1-106.7$ & 0.007 \\
\hline \multirow[t]{4}{*}{ Colostrums } & Total & $65 / 129$ & 2.09 & & $1.04-4.16$ & 0.036 \\
\hline & $>24 \mathrm{hrs}$ & $36 / 86$ & & 1 & & \\
\hline & $6-12 \mathrm{hrs}$ & $19 / 28$ & & 3.46 & $1.16-10.37$ & 0.02 \\
\hline & $<6 \mathrm{hrs}$ & $10 / 15$ & & 3.08 & $0.64-14$ & 0.15 \\
\hline \multirow[t]{3}{*}{ Bedding } & Total & $65 / 129$ & 3.84 & & $1.54-9.57$ & 0.004 \\
\hline & Yes & $23 / 60$ & & 1 & & \\
\hline & No & $42 / 69$ & & 4.7 & $1.85-12.08$ & 0.00 \\
\hline \multirow[t]{3}{*}{ Hygiene } & & & 0.58 & & $0.23-1.46$ & 0.246 \\
\hline & Poor & $29 / 49$ & & & & \\
\hline & Good & $36 / 80$ & & & & \\
\hline \multirow[t]{4}{*}{ Breed } & & & 0.51 & & $0.01-11.20$ & 0.49 \\
\hline & Local & $2 / 3$ & & & & \\
\hline & Cross & $63 / 126$ & & & & \\
\hline & Exotic & & & & & \\
\hline M. & $\mathrm{mut}$ & 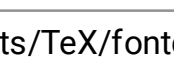 & - & & $0.16-0.96$ & 0.041 \\
\hline
\end{tabular}




\begin{tabular}{|lllllll|}
\hline Variable & Category & $\begin{array}{l}\text { Number } \\
\text { of + ve }\end{array}$ & $\begin{array}{l}\text { Crude } \\
\text { OR }\end{array}$ & $\begin{array}{l}\text { Adjusted } \\
\text { OR }\end{array}$ & 95\% Cl & p-value \\
\hline Same barn & $38 / 66$ & & 1 & & \\
\hline Pen & $27 / 63$ & & 0.41 & $0.17-0.98$ & 0.04 \\
\hline
\end{tabular}

Table 5

Antimicrobial susceptibility pattern of salmonella isolates to tested drugs

\begin{tabular}{|lllll|}
\hline & Antimicrobial agents & $\begin{array}{l}\text { No. of Susceptible } \\
\text { (\%) }\end{array}$ & $\begin{array}{l}\text { No. of Intermediate } \\
\text { (\%) }\end{array}$ & $\begin{array}{l}\text { No. of Resistant } \\
\text { (\%) }\end{array}$ \\
\hline 1 & Tetracycline & $7(87.5 \%)$ & $1(12.5 \%)$ \\
\hline 2 & Gentamicin & $6(75 \%)$ & $1(12.5 \%)$ & $1(12.5 \%)$ \\
\hline 3 & Chloramphenicol & $7(87.5 \%)$ & & $1(12.5 \%)$ \\
\hline 4 & Polymixin B & $8(100 \%)$ & $1(12.5 \%)$ & 0 \\
\hline 5 & Ampicillin & $7(87.5)$ & & \\
\hline 6 & Sulphamethoxazole & $8(100 \%)$ & & \\
\hline
\end{tabular}

Table 6

Multi-drugs resistance patterns of E.coli isolated from diarrheic calf

\begin{tabular}{|lll|}
\hline Frequency & Drugs & Percentages (\%) \\
\hline 1 & Tetra, sulpha囚trime & $5 \%$ \\
\hline 1 & Tetra ,Ampi & $5 \%$ \\
\hline 1 & Tetra, Ampi, PB & $5 \%$ \\
\hline 1 & Tetra, PB, Gent & $5 \%$ \\
\hline 1 & Tetra, chlorop, Ampi & $5 \%$ \\
\hline 2 & ST, Amp & $10 \%$ \\
\hline 2 & Ampi, PB & $10 \%$ \\
\hline 4 & Tetra, Chlorop & $10 \%$ \\
\hline 5 & Tetra, Gent & $20 \%$ \\
\hline 20 & Tetra, PB & $25 \%$ \\
\hline
\end{tabular}


Table 7

Antimicrobial susceptibility pattern of $E$. coli isolated from diarrheic calves.

\begin{tabular}{|c|c|c|c|c|c|}
\hline Antimicrobial agents & $\begin{array}{l}\text { Susceptible } \\
\mathrm{N}(\%)\end{array}$ & $\begin{array}{l}\text { Intermediate } \\
\mathbf{N}(\%)\end{array}$ & $\begin{array}{l}\text { Resistant } \\
\mathrm{N}(\%)\end{array}$ & $\begin{array}{l}\text { Total } \\
\text { N (\%) }\end{array}$ & $\begin{array}{l}\text { Susce } \\
\text { ptible } \\
N(\%)\end{array}$ \\
\hline \multirow[t]{2}{*}{ Tetracycline } & $27(41.54 \%)$ & 0 & $38(58.46$ & $65(100$ & $27(41$. \\
\hline & & & $\%)$ & $\%)$ & $54 \%)$ \\
\hline \multirow[t]{2}{*}{ Gentamicin } & $50(76.92 \%)$ & $9(13.85 \%)$ & $6(9.23 \%)$ & $65(100$ & $50(76$. \\
\hline & & & & $\%)$ & $92 \%)$ \\
\hline \multirow[t]{2}{*}{ Chloramphenicol } & $57(87.7 \%)$ & $4(6.2 \%)$ & $4(6.2 \%)$ & $65(100$ & $57(87$. \\
\hline & & & & $\%)$ & $7 \%)$ \\
\hline \multirow[t]{2}{*}{ Polymixin B } & $51(78.5 \%)$ & 0 & $14(21.54$ & $65(100$ & $51(78$. \\
\hline & & & $\%)$ & $\%)$ & $5 \%)$ \\
\hline \multirow[t]{2}{*}{ Ampicillin } & $48(73.85 \%)$ & $9(13.85 \%)$ & $8(12.31 \%)$ & $65(100$ & $48(73$. \\
\hline & & & & $\%)$ & $85 \%)$ \\
\hline sulphamethoxazole邓trimethpri & $61(93.85 \%)$ & 0 & $4(6.2 \%)$ & $65(100$ & $61(93$. \\
\hline $\mathrm{m}$ & & & & $\%)$ & 85\%) \\
\hline
\end{tabular}

\section{Antimicrobial susceptibility tests result}

Antimicrobial study of the isolates indicated that out of 65 isolates of $E$. coli, all of the isolates were highly susceptible to sulphamethoxazole冈trimethprim, chloramphenicol, gentamicin and ampicillin. Most of the isolates were highly resistant to tetracycline and followed by polymixin B, Ampicillin and Chloramphenicol, $29.23 \% 6.1 \%, 1.54 \%$ and $1.54 \%$ respectively. None of the isolates showed resistance for sulphamethoxazole邓trimethprim and gentamicin. From 8 isolates of salmonella all showed $100 \%$ susceptibility for sulphamethoxazole冈trimethprim and polymixin B, $87 \%$ to Ampicillin, chloramphenicol and tetracycline as well as $75 \%$ to gentamicin. Only one isolates showed mono drug (tetracycline) resistance.

\section{Discussion}

The present study was made to isolate and identify salmonella and $E$. coli in diarrheic calves, to assess the association of different risk factors and also to detect the antimicrobial susceptibility of those isolated bacteria's. Accordingly, the detection of $E$. coli in this study was $50.3 \%$, which is higher than the renorts of $[23 \cdot 24 \cdot 25 \cdot 29 \cdot 39$ and 91 who has renorted $44 \%, 43.1 \%, 23 \%, 25 \%, 49 \%$ and $38.6 \%$; respectively Loading [MathJax]/jax/output/CommonHTML/fonts/TeX/fontdata.js 
from different countries and lower than $[26 ; 27 ; 28 ; 31$ and 30$]$ who has reported $75 \%, 76 \%, 70.7 \%, 76 \%$, and $60 \%$ from different localities. The detection of salmonella in this study was $6.2 \%$ which is lower than the findings of [32] 13\%, [33] 9.61\% and [9] 21.9\%; and higher than the findings of [34]) $4 \%$, [25] 5\%. This prevalence difference may be due to the difference in sex, age and farm size of our study and others. As a result this study revealed that calf diarrhea was apparently higher in large sized dairy farms $(61.24 \%)$ than medium $(27.13 \%)$ and small dairy farms $(13.18 \%)$ though it was not statistically significant $(x 2=$ $2.15, P=0.34)$.

Similarly, diarrhea was highly associated with age of calves $(E$. coli, $x 2=9.249, \mathrm{p}=0.024$ and salmonella $(x 2=8.161, p=0.043)$. Calves in age group of 2 to 4 weeks were least susceptible while that of age group 0-2 weeks are highly susceptible and 5-8weekswere more resistant. The result can be associated with many factors, at younger age; delay in first

colostrums feeding was associated with higher risk of being affected with diarrhea. The finding that delayed colostrums intake (latter than 6 hours of age) associated with high risk of being affected with diarrhea reach agreement with other reports found that each hour of delay in colostrums ingestion in the first 12 hours of age increased the chance of a calf becoming ill by $10 \% .61 \%$ of colostral immunoglobulin containing $80 \mathrm{mg} / \mathrm{ml}$ of $43 \mathrm{lgG}$ is absorbed in six hours and decreases sharply thereafter [35].

This indicates that the first six hours are the period in which maximum absorption of colostral immunoglobulin takes place. Therefore, delays in administration could lead to lack of colostrums originated from maternal antibodies to protect calves from enteric pathogens [36; 37].

Another risk factor supposed with the occurrence of diarrhea associated with E. coli and salmonella was feeding colostrum. It was significantly associated with the occurrence of diarrhea $E$. coli, $(x 2=7.510, p=$ 0.023 ) and salmonella $(x 2=6.678, p=0.035)$. Sex of calves was also supposed to be risk factor associated with the prevalence of $E$. coli in diarrheic calves. As a result this study revealed that calf diarrhea was apparently higher in male calves $(35 / 65)$ than females calves $(30 / 65)(p=0.001)$. This may due to the male calf in dairy farms were not as much as needed in the production system and the producer mainly weaned the female (heifer) one for replacements.

The result also shows that the calves with severe diarrhea had highest percentage positivity to bacterial scours. This affirms the virulent ability of the organism to destroy the mucosa of the intestinal lining which affects the absorption and secretion ability of the gastro intestinal system and result in profuse watery foul smelling diarrhea. Management system of the farm also played a role in bacterial scours. Moreover, in this study diarrhea was highly associated with housing and $E$. coli as well as salmonella but it was not significant $(p=0.095)$. The intensive system of management had high percentage positivity to the disease while that with an extensive system of management had low percentage of positivity. This probably is due to free cycling of these bacteria between animals in a limited host environment once the pathogen gets access to the farm in animals kept indoors. The fact that the use of processed feed is Loading [MathJax]/jax/output/CommonHTML/fonts/TeX/fontdata.js ttdoors might also suggest the possibility of 
indoor kept animals being infected with bacteria from contaminated animal feed. It can be inferred that calves reared in extensive management have low risk of infection and are more resistant while those reared in intensive are exposed to causes of infection and less resistant to infection. Reasons for this could be poor hygiene in intensive, feeding animals with contaminated concentrates, hay and forages animal to make choice of what to eat could also be a contributing factor [11]. The earlier study has also shown livestock waste generated by animals consuming a diet chiefly composed of grass were less likely to harbor Salmonella spp. [38]. Therefore, satisfactory and essential attention should be given to management of calf by ensuring that the environment where calving takes place is disinfected properly from bacteria from previous calving, colostrums is taken by calf in the first few hours of life, in case of difficultly in feeding, and calf should be hand fed with feeders. Overcrowding of calves and lack of proper ventilation of the pen is also a risk factor and should be prevented as much as possible. Calf kept in housed pens should be housed individually in clean pens. Farms practicing intensive system of farming should pay ultimate attention to hygiene since they are at greater risk of the infection. I acknowledged limiting ourselves to isolation of bacterial pathogens in calves diarrheic cases in the course of this study due to the facts that other etiological agents such as viral, parasitic, fungal and even mycotic agents are not as common as bacterial pathogens, also approach to management of this condition require the use of an appropriate and most sensitive antibacterial agent.

In this study the highly sensitivity of E. coli to chloramphenicol and Sulfamethoxazole reach agreement with the reports of [28] and [30] and Sherwood and Snodgrass (1983) who found that all the isolates were sensitivity to chloramphenicol. These findings were in agreement with the results of Guerra et al. (2006) who stated that most of the microorganisms isolated from calves suffering from diarrhea were highly susceptible to chloramphenicol. The resistance percentage $(29.23 \%)$ of tetracycline in this study was in contrary with reported by [39] and [29] reported more than $80 \%$ and Hossain et al. (2012), documented $100 \%$ sensitivity to tetracycline.

\section{Conclusion And Recommendations}

The present study confirms the calf diarrhea was mainly caused by E. coli and sometimes there is involvement of pathogenic Salmonella species by isolating and identifiying and of E. coli and Salmonella from diarrheic calves in in the study area. This has showed that calf diarrhea was found to be high and could affect dairy production; and the detection of higher E. coli (50.3\%) and lower Salmonella $(6.2 \%)$ from diarrheic calves may be an indication for their importance in calves as causative agent for diarrhea in the study area. For the higher detection of $E$. coli from diarrheic calves in the study area sex, age and time of feeding colostrums were found to be incredibly important risk factors. With regarding to antimicrobial susceptibility most isolates were resistant to atleast one commonly used antimicrobials. This seeks attention from veterinary practitioners in order not to use antimicrobials simply without definitive diagnosis of the case. Although high percentage of $E$. coli were detected from diarrheic calves in and around Sebeta town, isolation of E. coli from feces may not be directly associated with causation of diarrhea. Since methods required for identifying pathogenic strains of $E$. coli are not established. 
Based on recent findings, we are highly recommending improved calf management practice, early colostrum feeding, and rational usage of antimicrobials.

\section{Declarations}

\section{Ethics approval and consent to participate}

Permission on ethical approval was obtained from the College of Veterinary Medicine Samara University. Fecal Samples were collected following prior explanation of the objectives of the study to the dairy farm owners and sampled based on their consent.

\section{Consent for publication}

Not applicable.

\section{Availability of data and material}

The datasets used and/or analyzed during the current study are available from the corresponding author on reasonable request.

\section{Competing interests}

The authors declare that they have no competing interests.

\section{Funding}

Not applicable

\section{Acknowledgements}

We acknowledge Samara University for job leave allowance to undertake this work and National animal health and diagnostic center, Sebeta for allowing us to do this research in their bacteriology laboratory. We wish to acknowledge personnel working in the dairy farms for their cooperation.

\section{References}

1. Solomon A, Authority ELM. (2003): Livestock marketing in Ethiopia: a review of structure, performance, and development initiatives (Vol. 52). ILRI (aka ILCA and ILRAD). 
2. Bereda A, Yilma Z, Nurfeta A. Dairy production system and constraints in Ezha districts of the Gurage zone, Southern Ethiopia. Global Veterinaria. 2014;12:181-6.

3. Thicket B, Mitchell D, Hallows B. Calf rearing. 2nd ed. Great Britain: biddies' Ltd; 2003. p..p.2131252.

4. Donovan GA, Dohoo IR, Montgomery DM, Bennett FL. Calf and disease factors affecting growth in female Holstein calves in Florida,USA. Prev Vet Med. 1998;33:1-10.

5. Radostits OM, Gay CC, Hinchcliff KW. Veterinary Medecine. aText book of diseases cattle sheep, pigs, goat and horse. 8th ed. London: Bailier tyndal; 2007. p..p. 847-1525.

6. Prescott BDM, Keel MK, Glock RD, Cuneo P, DeYoung DW, Reggiardo C, Trinh HT, Songer JG. A possible role for Clostridium difficile in the etiology of calf enteritis. Vet Microbiol Mar. 2008;18:127: 343-52.

7. Pereira RV, Santos TM, Bicalho ML, Caixeta LS, Machado VS. Antimicrobial resistance and prevalence of virulence factor genes in fecal Escherichia coli of Holstein calves fed milk with and without antimicrobials. J Dairy Sci. 2011;94:4556-65.

8. De Verdier K, Nyman A, Greko C, Bengtsson B. Antimicrobial resistance and virulence factors in E. coli from Swedish dairy calves. Acta Vet Scand. 2012;54:2.

9. Abdullah M, Akter MR, Lutful SM, Abu KM, Saleh IS. Aziz MA. Characterization of Bacterial Pathogens Isolated from Calf Diarrhoea in Panchagarh District of Bangladesh. J Agric Food Tech. 2013;3:8-13.

10. Cho YI, Kim WI, Liu S, Kinyon JM, Yoon KJ. Development of a panel of multiplex real-time polymerase chain reaction assays for simultaneous detection of major agents causing calf diarrhea in feces. $J$ Vet Diagn Invest. 2010;22:509-17.

11. Lorenz I, Mee JF, Earley B, More SJ. Calf health from birth to weaning. I. General aspects of disease prevention. Irish Vet Jour. 2011;64:10.

12. Bazeley K. Investigation of diarrhea in the neonatal calf. In Practice. 2003;25:152-9.

13. Lorino T, Daudin J, Robin S. Factors associated with time to neonatal diarrhea in French beef calves. Prev Vet Med. 2005;68:91-102.

14. Constable PD. Antimicrobial use in the treatment of calf diarrhea. J Vet Intern Med. 2004;18:8-17.

15. Orden J, Garcia S De La fuente R., (2000): Susceptibility of E. coli strains isolated from diarrheic dairy calves to 15 antimicrobials agents. J Ve Med., 47: 329-335.

16. Izzo M, Mohler V, House J. Antimicrobial susceptibility of Salmonella isolates recovered from calves with diarrhoea in Australia. Aust Vet J. 2011;89:402-8.

17. Kaura Y, Bhargava D, Pruth A, Prasad S. Isolation of multiple antibiotic resistant strains of $E$. coli from in turkey poultry. Indian J Poultry Sci. 1988;23:123-34.

18. Perez E. Infectious agents associated with diarrhoea of calves in the canton of Tilaran, Costa Rica. Prev Vet Med. 1998;33:195-205. 
19. Lemma M, Kasha T, Azage T. Clinically manifested major health problems of cross breed dairy breeds in urban and peri urban production systems in central highlands of Ethiopia. Trop Anim Health Prod. 2001;33:85-93.

20. Gershwin LJ. Physiochemical and biological basis of immunity. In: Biberstein EL, Zee YC, editors. Review of Veterinary Microbiology. Boston: Blackwell Scientific Publications; 1990. pp. 29-30.

21. Koneman EW, Allen SD, Janda WM, Schreckenberger PC, Winn WC. (1997): Diagnostic microbiology. The nonfermentative gram-negative bacilli. Philedelphia: Lippincott-Raven Publishers, 253-320.

22. Edwards PR, Ewing WH. Identification of Enterobacteriaceae Emerg. Infect Dis. 1972;12:154-9.

23. Quinn PJ. (1994). Clinical veterinary microbiology (No. SF 780.2. C54 1994).

24. Masud M, Fakhruzzaman $\mathrm{M}, \mathrm{Nazir} \mathrm{H}$. Isolation of $E$. coli from apparently healthy and diarrheic calves in Bangladesh and their antibiogram. J Bang Soc Agric Sci Technol. 2012;9:45-8.

25. Dereje W. (2012): Isolation and identification of Enterobacteria species from diarrheic calves in and around Addis Ababa, Ethiopia, 6: 2474-7637.

26. Joon DS, Kaura YK. Isolation and characterization of some of the enterobacteriaceae from diarrhoeic and non-diarrhoeic calves. Indian J Anim Sci. 1993;63:373-83.

27. Hemashenpagam N, Kiruthiga T, Panneerselvam A. Isolation of bacterial cause of calf diarrhea with special reference to E. coli. The Internet J Micro. 2009;7:10-28.

28. Paul $\mathrm{K}$, Khan M, Mahmud S. Isolation and characterization of $E$. coli from buffalo calves in some selected areas of Bangladesh.Bangl. J Vet Med. 2010;8:23-6.

29. Yeshiwas T, Fentahun WM. The Prevalence of E. coli From Diarrheic Calves and Their Antibiotic Sensitivity Test in Selected Dairy Farms of Debre Zeit, Ethiopia. Adv Biotech Micro. 2017;6:27.

30. Ansari RH, Rahman MM, Islam MJ, Das BC, Habib A, Belal SH, Islam K. Prevalence and antimicrobial resistance profile of Escherichia Coli and Salmonella isolated from diarrheic calves. JAnim Hlth Prod. 2014;2:12-5.

31. Nazir K. Antibiogram pattern of E. coli isolates of calves feces and diarrhegenic stool of infants. J Bangla Soci Agri Sci Techno. 2007;4:49152.

32. Eguale T, Engidawork E, Gebreyes WA, Asrat D, Alemayehu H, Medhin G, Gunn JS. Fecal prevalence, serotype distribution and antimicrobial resistance of Salmonellae in dairy cattle in central Ethiopia. BMC microbiology. 2016;16:20.

33. El-Rahman AMA, Mahmoud AEKA, Khadr AM, El-Shemy TM. Some Studies on Salmonella Enterica Associated with Diarrhea in Cattle. Alex J Vet Sci. 2016;48:54-60.

34. Hoque MS, Samad MA. Prevalence of clinical diseases in dairy Cross -bred cows and calves in the urban areas in Dhaka. Bangladesh Vet J. 1996;30:118-29.

35. Amruta NT, Balasaravanan SV, Malik S, Vysakh M, Manesh K, Jess V, Deepak BR. Isolation and identification of Salmonella from diarrheic infants and young animals, sewage waste and fresh vegetables. Vet World. 2015;8:669. 
36. Matte JJ, Girard CL, Seoane JR, Brisson GJ. Absorption of colostral immunoglobulin G in the newborn dairy calf. J Dairy Sci. 1982;65:1765-70.

37. Temesgen W. (2004): Calf morbidity and mortality in dairy farms in Debre Zeit and its environs, Ethiopia.

38. Godden S. (2007): Colostrum's management for dairy calves in proceedings from the conference calf management Siolheim Hansen.

39. Hutchison ML, Walters LD, Avery SM, Munro F, Moore A. Analyses of livestock production, waste storage, and pathogen levels and prevalence's in farm manure. Appl Environ Microbiol. 2005;:71:1231-6.

40. Mailk S, Kumar A, Verma AK, Gupta MK, Sharma SD, Sharma AK, AnuRahal. Incidence and Drug Resistance Pattern of Collibacillosis in Cattle and Buffalo Calves in Western Utter Pradesh in India. J Anim Health Prod. 2013;1:15-9.

41. ISO. Microbiology of food and animal feeding stuffs. Horizontal methods for the detection of salmonella species. Geneva: international organization standardization; 2002.

42. Clinical and Laborator Standards Institute (CLSI Microbiology. Clinical and Laborator Standards Institute (CLSI, (2013); Performance Standards for Antimicrobial Susceptibility Testing Twenty first Informational Supplement M100-S21. Wayne, PA, USA. 